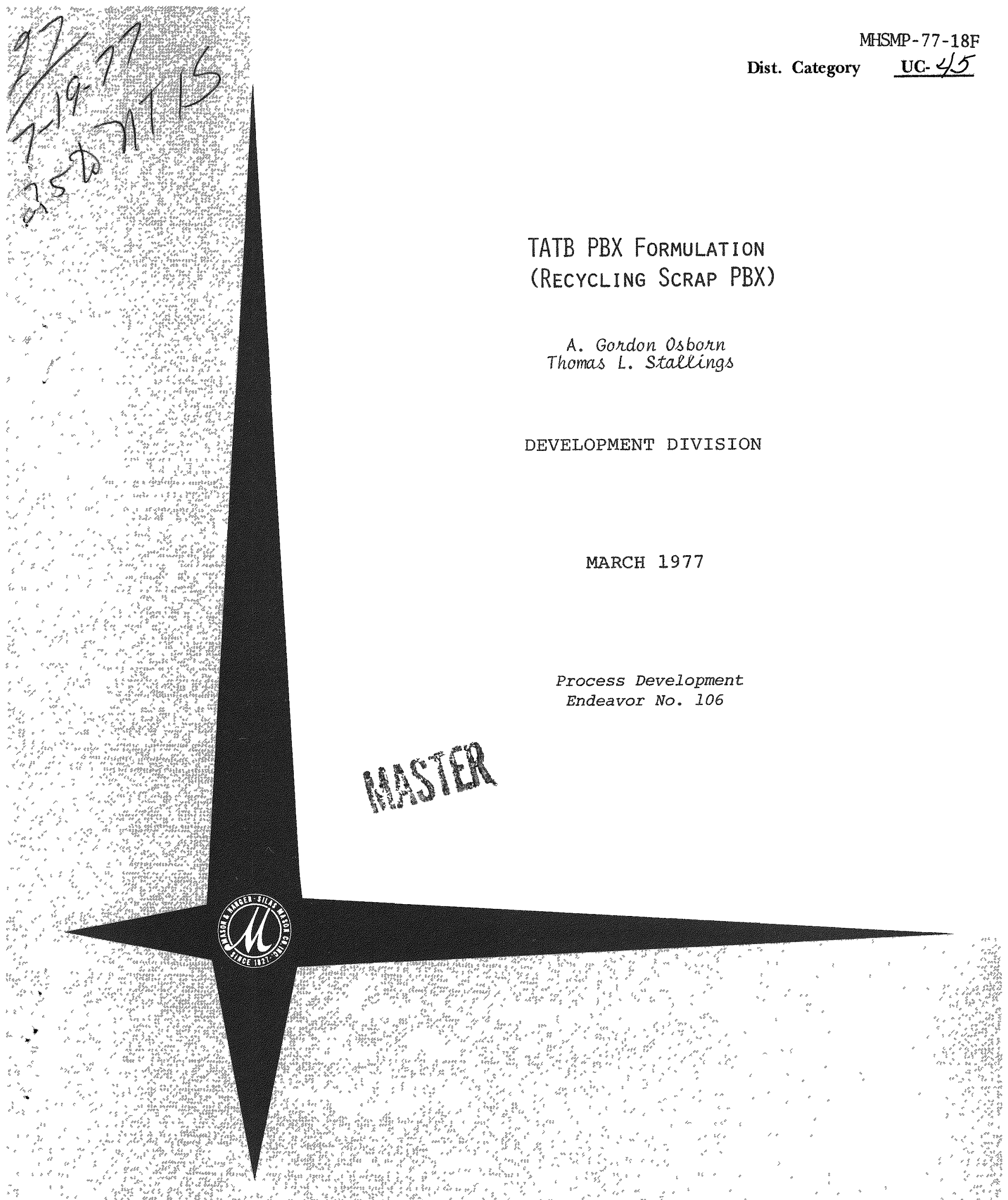

\title{
TATB PBX FORMULATION (RECYCLING SCRAP PBX)
}

\author{
Thomas L. Stallings
}

rocess Development

Endeavor No. 106 


\section{NOTICE}

This report was prepared as an account of work sponsored by the United States Government. Neither the United States nor the United States Energy Research and Development Administration, nor their employees, nor any of their contractors, subcontractors, or their employees, makes any warranty, express or implied, or assumes any legal liability or responsibility for the accuracy. completeness or usefulness of any information, apparatus, product or process disclosed, or represents that its use would not infringe privately-owned rights. 


\section{DISCLAIMER}

This report was prepared as an account of work sponsored by an agency of the United States Government. Neither the United States Government nor any agency Thereof, nor any of their employees, makes any warranty, express or implied, or assumes any legal liability or responsibility for the accuracy, completeness, or usefulness of any information, apparatus, product, or process disclosed, or represents that its use would not infringe privately owned rights. Reference herein to any specific commercial product, process, or service by trade name, trademark, manufacturer, or otherwise does not necessarily constitute or imply its endorsement, recommendation, or favoring by the United States Government or any agency thereof. The views and opinions of authors expressed herein do not necessarily state or reflect those of the United States Government or any agency thereof. 


\section{DISCLAIMER}

Portions of this document may be illegible in electronic image products. Images are produced from the best available original document. 


\title{
TATB PBX FORMULATION \{RECYCLING SCRAP PBX\}
}

\author{
A. Gordon Osborn \\ Thomas L. Stallings \\ DEVELOPMENT DIVISION \\ Process Development \\ Endeavor No. 106
}

\begin{abstract}
Three 300-galion batches of $\mathrm{RX}-03-\mathrm{BB}$ containing machining scrap were processed. Portions of new TATB powder were mixed with the machining scrap in two of the batches. The third batch consisted of $100 \%$ scrap PBX and was made by the Holston processing method. Tensile strength of all three batches were adequate with the batch containing 50\% new TATB powder giving the superion properties.

Thirty-litre batches of scrap PBX were processed to evaluate the effect of additives. Dapon $M$ offered some improvement in physical properties.
\end{abstract}

\section{INTRODUCTION}

Reclaiming of TATB PBX machining waste or scrap is of major interest due to the high cost of the TATB and the large quantity of scrap which will be generated.

\section{LARGE SCALE PROCESSING 300-GALLON KETTLE}

Tensile strength data for three large lots processed in the 300-gallon kettle are given in Fig. 1. The material which contained new TATB powder mixed with machining scrap was made by the standard Pantex process while the batch containing all machine scrap with no new TATB was made by the holston ethyl acetate process.
As shown in the results, all three batches had reasonable high stress with adequate strain. The batch containing $50 \%$ new TATB, however, had the highest strain value.

\section{PANTEX PROCESS}

The standard Pantex slurry procedure involves a $133 \mathrm{~g} /$ litre $\mathrm{HE}$-to-water ratio with heat and an air sweep to remove the solvent. The RX-03-BB machine cuttings and a water-immiscible solvent pair, MIBK and NBA, are added at a low water level to the reactor to form the slurry. The water level is then raised and heat is applied for subsequent solvent evaporation and granulation. 


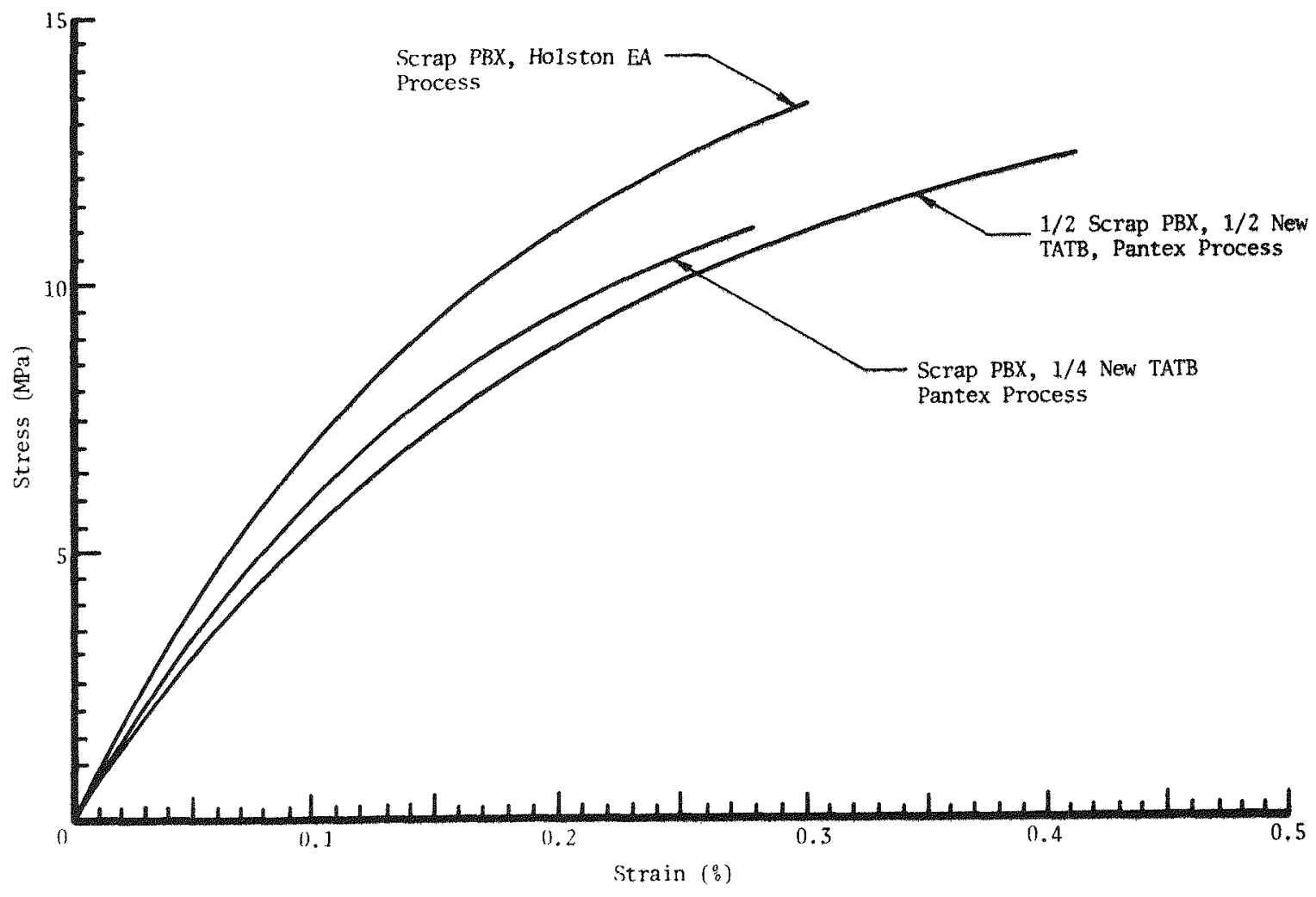

Fig. 1. Ionile Strength, RX-03-BB - Recycled Scrap PBX

\section{HOLSTON PROCESS}

A higher $\mathrm{HE}$-to-water ratio is used in the Holston process and the granules are made by adding quench water to extract the solvent, thus causing the formation of the granules. After a granule aging or annealing period the solvent is removed with heat.

\section{RECLAIMED TATB PBX WITH ADDITIVES}

An experimental series to evaluate the effect of additives was performed in the 30-1itre reactor using the Pantex slurry procedure. Results are summarized in Fig. 2. Two additives, TNT and Dapon M, were evaluated. Dapon $M$ is dially1 isophthalate prepolymer manufactured by FMC Corporation.
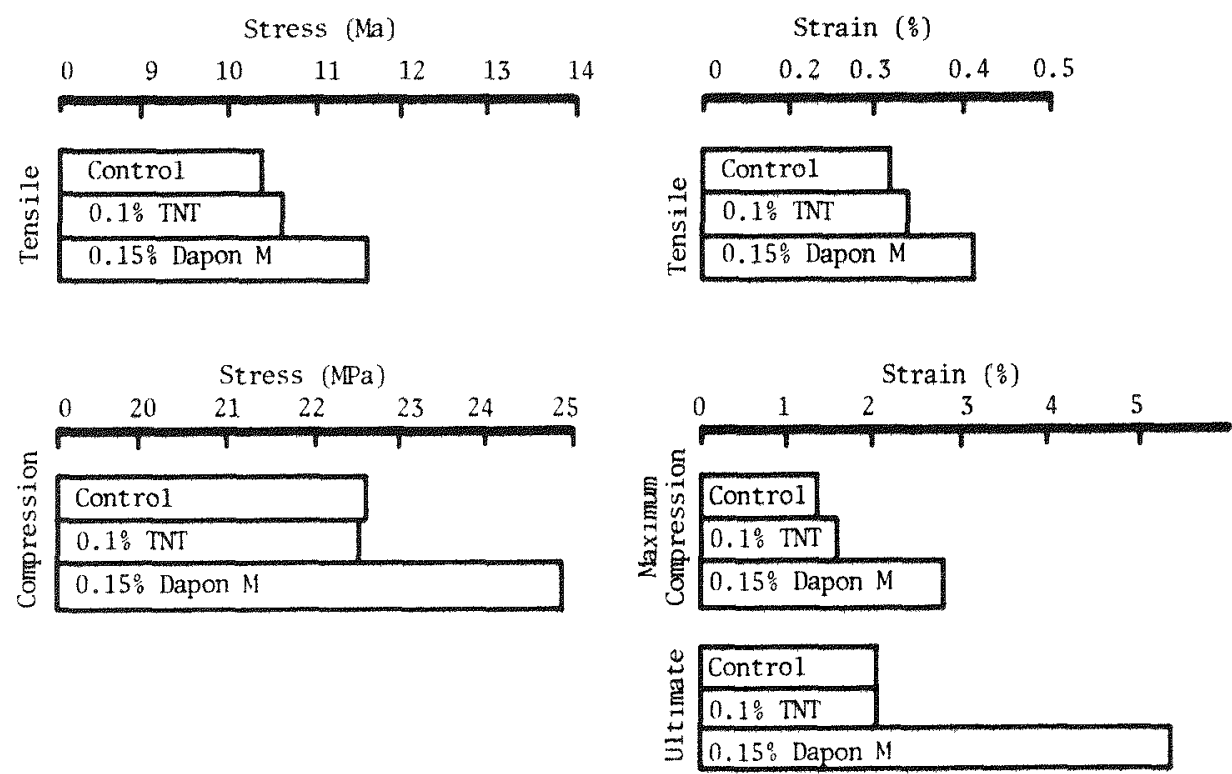

11g. 2. Physical Strength of Reclaimed RX-0.3-BB With Additives 


\section{CONCLUSIONS}

The results clearly show that large scale processing of TATB PBX machining scrap is feasible. Physical properties, specifically tensile strain, appear to be improved by the addition of new TATB powder.
The addition of $0.1 \%$ TNT did not appear to influence or improve physical properties. However, Dapon $\mathrm{M}$ offered some improvement for both compression and tensile stress and strain. The physical properties of the recycled scrap were more nearly similar to the physical properties of PBX made from new TATB powder. 